\title{
Mathematical Problem Solving: Variables that Affect Problem Solving Success
}

\author{
Dilek Sezgin Memnun (Corresponding author) \\ Dept. of Elementary Education, Uludag University \\ Ozluce mah. 16120 Nilufer, Bursa, Turkey \\ Tel: 90-532-720-9172Ｅ-mail: dilekmemnun@gmail.com \\ Merve Coban \\ Secondary School Mathematics Teacher \\ Mersin, Turkey \\ Tel: 90-536-794-5379 E-mail: merve.math.09@gmail.com
}

Received: May 11, 2015 Accepted: June 23, 2015 Published: July 29, 2015

doi:10.5296/ire.v3i2.7582 URL: http://dx.doi.org/10.5296/ire.v3i2.7582

\begin{abstract}
Individuals who can solve the problems in everyday and business life is one of the primary goals of education due to the necessity to have problem solving skills to cope with life problems. Problem solving has an important role in mathematics education. Because of that, this research is aimed to examine the differentiation of secondary school students' problem solving success according to gender, class level, and mathematics course grade. Moreover, this paper explores the effect of secondary school students' attitudes toward mathematics and problem solving on problem solving success. The participants were 77 fifth-graders and 81 sixth-graders who were studying in three different secondary schools in a large city in Turkey. Two different attitude instruments and a problem solving test were administered to these volunteer fifth- and sixth-graders accompanied by mathematics teachers. Additionally, the students' mathematics course grades for the fall semester were obtained and used in the research. The results revealed that sixth-graders were more successful in problem solving than fifth- graders. The problem solving success of female and male students was similar, and there was an intermediate positive relationship between problem solving success and course grade point averages. The students' attitudes affected their problem solving success.
\end{abstract}


Keywords: Problem solving, Attitudes, Gender, Middle school students.

\section{Introduction}

Problem solving has an important role in mathematics education. For all that, mathematics education based on problem solving is an issue that only began to be investigated in the last century though this important role of it (Cai, 2003).

There are different definitions of problem and problem solving. Most commonly, a problem can be considered a "situation that cannot be solved by an ongoing reaction" (Acikgoz, 2002). Similarly, a problem can be defined as a situation that involves "the need to search for a solution with the help of individuals' knowledge and experience when they face an event that disturbs them" (Baki, 2006, pp. 146). A problem requires an answer, but solutions may not be found easily (Schoenfeld, 1992). It involves a situation in which individuals do not know what to do when they face a difficulty. Individuals understand the situation, but they may not be able to find a strategy to immediately identify a solution (Reys, Suydam, Lindquist, \& Smith, 1998). According to the National Council of Teachers of Mathematics (1989), problem solving is not an issue, but is a process that provides conditions in which individuals learn skills. As a result, problem solving requires curiosity, creative talent, and discovery (Polya, 1990).

Mathematics problems can be classified as word or real problems according to the data obtained and as routine or non-routine problems according to their way of thinking (Van de Walle, 1994). Routine problems are problems that students encounter in daily life and that require the ability to perform arithmetic operations. These problems require the application of a formula that students apply to a new situation. Teaching this type of problem is very important for the development of problem solving skills (Polya, 1990: pp. 168-169). Word problems come to mind first when we think of problems in mathematics courses. These problems are problems that are constructed by assuming a case that does not actually exist. The data for these problems are based on actual data and are similar to data that may occur in the real world. Word problems have come to the fore in mathematics education programs because everyday life is full of these problems. Because of that, these problems contribute to the development of operational skills required for daily life, the creation of a model for real life problems, and the mathematical development of students (Aydogdu \& Olkun, 2004). These problems are also important means of gaining basic skills, such as organizing lists and drawing figures (Reusser \& Stebler, 1997).

\subsection{Related Research}

Various international studies related to problem solving (Altun, 1995; Bourke \& Stacey, 1988; Byron, 1995; Kupcu \& Ozdemir, 2012; Oladunni, 1998; Ozsoy, 2005) were carried out with elementary and secondary school students and focused on the analysis of these students' problem solving skills, and the differentiation of the skills or success according to different variables.

Altun (1995) reported that mathematical problem solving success and attitudes toward mathematics among primary third-, fourth- and fifth-graders are related. This relationship was 
found to be greater in fourth-grade compared to the other grade levels. Bourke and Stacey (1988) indicated that four-, five- and six-year children's problem solving performance did not differ according to genders, and four-year students' performance was generally lower than other students. Byron (1995) declared that eighth-grade female students' beliefs about mathematical problem solving sufficiency were important for problem solving success. Kupcu and Ozdemir (2012) reported that seventh-graders' solving success for problems related to unknown values, quantitative comparisons, ratios, percentages, and similarity in triangles did not differ according to gender. Besides, it was found that seventh- and eighth-graders' mathematical problem solving success related to unknown values, ratios, and quantitative comparison problems differs according to class levels, whereas their mathematical problem solving success related to perception and similarity in triangles did not differ according to class levels. Oladunni (1998) stated that there was no significant difference in the creative problem solving success of male and female secondary school students. Ozsoy (2005) reported that there was a significant and positive relationship between solving skills and mathematics success among fifth-graders.

\subsection{Research Focus}

Training individuals who can solve the problems they may encounter in everyday and business life is one of the primary goals of education. Accordingly, it is necessary to have problem solving skills to cope with life problems.

Individuals can understand and use mathematical knowledge in the problem solving process, and they can use this knowledge to develop new mathematical insights (NCTM, 2000). Individuals develop critical, creative, and reflective thinking skills and use analysis and synthesis in the problem solving process (Soylu \& Soylu, 2006). Additionally, problem solving sparks students' interest and encourages them to think and solve problems (Katwibun, 2004). Especially, routine word problems provide a suitable environment for mathematical reasoning and development (Reusser \& Stebler, 1997). These problems are suitable for lower age groups (Aydogdu \& Olkun, 2004, pp. 27-38), and are widely used in schools. Therefore, it is important for students in elementary and secondary grades to be able to solve this type of problems. Nevertheless, many students do not possess sufficient knowledge and skills that are based on learning, thinking and problem solving abilities in today's schools (De Corte, 2003). Students think mathematics as a domain, which is independent of other domains, that certain rules are applied directly, where problems have one correct solution, and where the mathematical understanding requires a special ability (Lampert, 1990; Schoenfeld, 1992). This situation, which is still valid in schools, frightens the students and makes them weak-spirited. Within this framework, the primary aim of the current study is to focus on the changes of routine problem solving skills and success of secondary students according to different affective variables. Besides, different variables such as emotional states, including their beliefs and attitudes regarding mathematics could affect individual's problem solving abilities and; therefore problem solving success (Altun, 1995; Byron, 1995; McLeod, 1992, pp. 575; Ozsoy, 2005). Although different studies have examined problem solving skills and success, there have been few studies on the differentiation of problem solving skills and success of secondary school students according to different affective variables such as 
attitudes. Hence, there is a need for research on the differentiation of affective variables on students' word problem solving success.

\subsection{Research Questions}

The present study aims to examine the differentiation of secondary school students' problem solving success according to gender, class levels, and mathematics course grades. Additionally, this study aims to explore the effect of secondary school students' attitudes toward mathematics and problem solving on mathematical problem solving success. Therefore, this study aims to answer the following research questions:

1. Does the problem solving success of fifth- and sixth-graders show significant differences according to gender or class levels?

2. Is there a relationship between the problem solving success of fifth- and sixth-graders and their grade point averages?

3. What is the fifth- and sixth-graders' attitudes towards mathematics or problem solving in predicting their mathematical problem solving success?

\section{Methodology}

\subsection{Participants}

The participants in this research were 158 fifth- and sixth-graders who were studying in three different secondary schools in a large city in Turkey during the 2012-2013 academic year spring semester, including 77 fifth-graders and 81 sixth-graders. These schools and students were selected randomly. Seventy-eight of these students were males, and 80 were females.

\subsection{Data Collection Instruments}

Data for the research were obtained using three instruments. Two of these instruments, the Attitudes Towards Mathematics Instrument and the Problem Solving Attitudes Scale, are 5-point Likert instruments. The Attitudes Towards Mathematics Instrument was developed by Askar (1976), and the Problem Solving Attitudes Scale was developed by Canakci and Ozdemir (2011). The last instrument was a Problem Solving Test that included ten open-ended word problems prepared from various sources. This test examined compliance in terms of level, scope, content, and language by two different secondary mathematics teachers. These problems were different types of problems that offered students the opportunity to use their knowledge of mathematics.

The Problem Solving Attitudes Scale, which aims to measure the problem solving attitudes of secondary school students, is a 19-item scale. It contains 8 negative and 11 positive items grouped into 2 main dimensions, enjoyment and teaching. The highest point value that can be obtained for this scale is 95 , and the lowest is 19 . The items related to the enjoyment dimension generally reflect students' likes and dislikes about problem solving as well as attitudes toward compulsive and boring cases in problem solving. The items related to the teaching dimension reflect students' attitudes toward the teaching process of problem solving. The total variance for both factors was determined to be $42.69 \%$. The Pearson correlation coefficient calculated 
using the test-retest technique .89. Cronbach's alpha coefficients for the enjoyment and teaching main dimensions of this instrument were calculated at .85 and .78 . Additionally, the Cronbach's alpha coefficient for this scale was calculated as .83 for the data obtained from this study.

The Attitudes Towards Mathematics Instrument contains a total of 20 points, including 10 negative and 10 positive points. The highest point value that can be obtained for this scale is 100 , and the lowest is 20 . The Cronbach's alpha coefficient for this instrument was .94 for the data obtained from this study. The reliability of the test scores is generally sufficient when the reliability coefficients higher than .70 (Buyukozturk, 2010, pp. 170). This situation indicates that the measurement points were sufficient for these two instruments.

\subsection{Data Collection}

These two instruments and the problem-solving test were administered to the volunteer participants accompanied by mathematics teachers at different times during the spring semester of the 2012-2013 academic year. Secondary school fifth- and sixth-graders volunteered to participate in this study and completed the Problem Solving Attitudes Scale and the Attitudes Towards Mathematics Instrument within 30 minutes. These students also completed the Problem Solving Test within 40 minutes. Additionally, the students' mathematics course grades for the fall semester of the 2012-2013 academic year were obtained and used in this research.

\subsection{Data Analysis}

The average points were calculated by dividing the total points obtained from the Problem Solving Attitudes Scale and the Attitudes Towards Mathematics Instrument by the number of items. Higher average points on these instruments indicate positive attitudes. Each of the word problems was coded as follows: 10 points for a correct, 5 points for a partially correct, and 0 points for an incorrect response. Thus, the students' qualitative responses to these open-ended problems were transformed into quantitative responses. The total points were calculated for each student's test and the average test scores were divided into the number of problems.

A Kolmogorov-Smirnov $\mathrm{Z}$ test was used to test the normality of the data distribution, and Levene statistics were used to test the homogeneity of the data. As a result of the examination, it was determined that the distribution of data for each data group showed a homogeneous distribution. Therefore, an independent samples t-test was first performed to differentiate the students' problem solving success according to gender, and to class levels. After that, a correlation analysis was performed to determine whether there is a relationship between the mathematical problem solving success of students and mathematics course grade point averages. Finally, the regression analysis was performed to determine whether or not the fifth- and sixth-graders' attitudes towards mathematics average scores and class levels can predict their problem solving attitudes average scores. Similarly, it was performed to determine whether or not these students' enjoyment and teaching domain average scores related to problem solving attitudes, and class levels can predict their problem solving attitudes average scores. Buyukozturk (2010, pp. 32) posited that a Pearson correlation 
coefficient between 0.30 and 0.00 indicates a low-level relationship; a coefficient between 0.70 and 0.30 indicates a medium-level relationship; and a score between 1.00 and 0.70 indicates a high-level relationship. For all of the statistical decoding, .05 significant levels were used as the base. The data were analyzed using the SPSS 14.0 program.

\section{Research Results}

Independent samples t-test was first performed to differentiate the students' problem solving success according to gender, and to class levels. The analysis results are presented in Table 1.

Table 1. The differentiation of problem solving success according to gender and grades

\begin{tabular}{llcccccc}
\hline \multirow{2}{*}{ Gender } & & $\mathrm{N}$ & $\bar{x}$ & $\mathrm{~S}$ & $\mathrm{df}$ & $\mathrm{t}$ & $\mathrm{p}$ \\
& Female & 78 & 37.89 & 23.56 & \multirow{2}{*}{156} & -1.175 & \multirow{2}{*}{.242} \\
\hline \multirow{2}{*}{ Grades } & Male & 80 & 42.31 & 23.79 & & & \\
& Female & 78 & 35.13 & 21.24 & \multirow{2}{*}{0} & \multirow{2}{*}{$-2.632^{*}$} & .009 \\
& Male & 80 & 44.88 & 25.04 & 156 & & \\
\hline
\end{tabular}

${ }^{*} \mathrm{p}>05$

The table indicates that there is no significant difference between the mathematical problem solving success of female and male secondary school students who participated in this research $[\mathrm{t}(156)=-1.175 ; \mathrm{p}>.05]$ while there is a significant difference between the problem solving success of these students $[\mathrm{t}(156)=-2.632 ; \mathrm{p}<.05]$. This finding indicates that the problem solving success of the male and female students is at a similar level. Conversely, the average of problem solving success score of the fifth-graders $(\bar{x}=35.13)$ was much lower than the solving success score of the sixth-graders $(\bar{x}=44.88)$. This finding indicates that the problem solving success of the sixth-graders is at a higher level than the success of the fifth-graders.

Secondly, a correlation analysis was performed to determine whether there is a relationship between the mathematical problem solving success of students and mathematics course grade point averages (Table 2).

Table 2. Correlations between problem solving success and grade point averages

\begin{tabular}{lc}
\hline & Problem Solving Success \\
\hline Grade Point Averages & $.604^{*}$ \\
\hline${ }^{*}<.01$
\end{tabular}

The results of the analysis show a middle-level, positive relationship between the problem solving success and students' mathematics course grade point averages $(r=0.604, p<.01$, $\mathrm{n}=158$ ). 
Finally, the first regression analysis was performed to determine whether or not the fifth- and sixth-graders' attitudes towards mathematics average scores and class levels can predict their problem solving attitudes average scores. Similarly, the second regression analysis was performed to determine whether or not these students' enjoyment and teaching domain average scores related to problem solving attitudes, and class levels can predict their problem solving attitudes average scores. The results of these regression analysis are presented in Table 3.

Table 3. Model summary of regression analysis

\begin{tabular}{|c|c|c|c|c|c|}
\hline & \multicolumn{5}{|c|}{ Mathematical Problem Solving Success } \\
\hline & $\mathrm{B}$ & $\begin{array}{l}\text { Std. } \\
\text { error }\end{array}$ & $\beta$ & $\mathrm{t}$ & $\mathrm{p}$ \\
\hline Attitudes Towards Mathematics & 6.804 & 2.378 & 0.222 & 2.861 & .005 \\
\hline Class Levels & 11.377 & 3.665 & 0.241 & 3.104 & .002 \\
\hline $\mathrm{R}=0.301$ & \multicolumn{2}{|c|}{$\mathrm{R}^{2}=0.091$} & \multicolumn{2}{|c|}{$F(2,155)=7.716$} & $\mathrm{p}=.001$ \\
\hline $\begin{array}{ll}\text { Problem } & \text { solving } \\
\text { (enjoyment) } & \end{array}$ & 7.665 & 2.069 & 0.287 & 3.705 & .000 \\
\hline \multirow{2}{*}{$\begin{array}{l}\text { Problem solving attitudes (teaching) } \\
\text { Class levels }\end{array}$} & 2.747 & 1.898 & 0.110 & 1.448 & .105 \\
\hline & 13.230 & 3.623 & 0.280 & 3.651 & .000 \\
\hline $\mathrm{R}=0.377$ & $\mathrm{R}^{2}=$ & 142 & $\mathrm{~F}(3,154)=$ & 8.503 & $\mathrm{p}=.000$ \\
\hline
\end{tabular}

Problem solving success average scores of fifth- and sixth-graders' attitudes toward mathematics scores and class levels did predict together their mathematical problem solving success average scores $[\mathrm{p}<.01, \mathrm{df}=2, \mathrm{~F}(2,155)=7.716]$. However, this result may not generalize beyond the population under study, as evidenced by the low $\mathrm{R}$ square value $\left(\mathrm{R}^{2}=.091\right)$ reported in this research. The $\mathrm{R}$ square value of .091 reveals that these students' attitudes toward mathematics scores and class levels together accurately predict $9.1 \%$ of the mathematical problem solving success average scores of fifth- and sixth-graders. As shown in Table 3, the first regression analysis results showed that both of the attitudes toward mathematics and class levels of fifth- and sixth-graders are important predictors of their mathematical problem solving success. The two predictor variables showed significant contributions to the regression model: Attitudes towards mathematics ( $B=6.804, \beta=0.222$, $\mathrm{p}=.005)$, and class levels $(\mathrm{B}=11.377, \beta=0.241, \mathrm{p}=.002)$. Both of these variables provided positive contribution to this regression model.

Similarly, the second regression analysis results showed that problem solving success scores of fifth- and sixth-graders' enjoyment and teaching domain average scores, and class levels did predict together their problem solving success average scores $[\mathrm{p}=.000, \mathrm{df}=3, \mathrm{~F}(3,154)=$ 8.503]. However, this result may not generalize beyond the population under study, as evidenced by the low $\mathrm{R}$ square value $\left(\mathrm{R}^{2}=.142\right)$ reported in this research. The $\mathrm{R}$ square value of .142 reveals that these graders' enjoyment and teaching domains related to problem 
solving, and class levels together accurately predict $14.2 \%$ of the problem solving success of them. Additionally, the enjoyment domain related to problem solving attitudes, and class levels of the students are important predictors of their problem solving success. Two of these predictor variables showed significant contributions to the regression model: Enjoyment $(B=7.665, \beta=0.287, p=.000)$, and class levels $(B=13.230, \beta=, p=.002)$. Both of these variables provided positive contribution to this regression model while teaching domain related to problem solving attitudes not.

\section{Discussion and Conclusion}

Teachers and learners need to improve their skills in the adopting problem-solving approaches and different variables could affect problem solving abilities and; therefore problem solving success of individual (Altun, 1995; Byron, 1995; Ozsoy, 2005). Consequently, this study examined the differentiation of secondary school students' problem solving success according to gender, class levels, and mathematics course grades. Furthermore, it explored the effect of these students' attitudes towards mathematics and problem solving on problem solving success.

The results indicate that sixth-graders are more successful in mathematical problem solving than fifth-graders, whereas the problem solving success of female and male secondary school students is similar. This result is supported by Fitzpatrick (1994), and Oladunni (1998). Similar results have been found by Bourke and Stacey (1988), Kupcu and Ozdemir (2012). Moreover, the statistical analysis indicates that mathematical problem solving success and students' mathematics course grade point averages are related. Similar results have been found in research conducted by Kupcu and Ozdemir (2012), Oladunni (1998), and Ozsoy (2005).

The regression analysis results indicate that fifth- and sixth-graders' attitudes toward mathematics and class levels are important predictors of mathematical problem solving success. This means that these students' attitudes toward mathematics and class levels affect their mathematical problem solving success. This result is similar to the results presented by Altun (1995) and Byron (1995). Attitudes toward mathematics and class level variables are significant predictors of fifth- and sixth-graders' problem solving success. These variables explain $9.1 \%$ of students' success. Similarly, the results indicate that secondary school students' mathematical problem solving attitudes, including enjoyment and teaching dimensions and class levels, are important predictors of problem solving success. Attitudes toward mathematics and class level variables are significant predictors of fifth- and sixth-graders' problem solving success. These variables explain $14.2 \%$ of students' problem solving success.

Beliefs and attitudes affect students' problem solving behavior; accordingly, these are aspects to be improved (Fitzpatrick, 1994; Van de Walle, 1994). In this study, it has been indicated that attitudes toward mathematics or mathematical problem solving affect students' mathematical problem solving success. It has been also found that mathematical problem solving skills and success of secondary school students differ according to class levels in this current study. Additionally, some research (Ozsoy, 2005) state that some different variables 
such as academic language proficiency, thinking skills, mathematics success, problem-based learning could affect mathematical problem solving ability and problem solving success. Therefore, future research may focus on the development of different affective variables to help students become successful problem solvers or problem solving skills and success in different class levels.

\section{Acknowledgement}

The research is presented in the 2nd International Conference on New Trends in Education, May 29-31, 2015, Bahçeşehir University, Istanbul, Turkey.

\section{References}

Acikgoz, K. (2002). Aktif ogrenme (Active learning). İzmir, Turkey: Egitim Dunyasi.

Altun, M. (1995). A research on the problem solving behaviours of third, fourth and fifth graders). (Doctoral dissertation). Ankara, Turkey: Hacettepe University.

Aksar, P. (1976). Matematik dersine yonelik tutumu olcen likert tipi bir olcegin gelistirilmesi. Education and Science, 11, 31-36.

Aydogdu, T., \& Olkun, S. (2004). Elementary school students' successes in choosing an operation for additive word problems. Eurasian Journal of Educational Research, 16(4), 27-38.

Baki, A. (2006). Kuramdan uygulamaya matematik egitimi. Trabzon, Turkey: Derya.

Bourke, S., \& Stacey, K. (1988). Assessing problem solving in mathematics: Some variables related to student performance. Australian Educational Researcher, 15(1), 73-83. http://dx.doi.org/10.1007/BF03219402

Buyukozturk, S. (2010). Sosyal bilimler icin veri analizi kitabı (Data analysis handbook). Ankara, Turkey: PegemA.

Byron, M. K. (1995). Confronting the verbal/visual issue: The mathematical problem-solving processes of a small group of female junior secondary students. (Doctoral dissertation). Columbus, OH: Ohio State University.

Cai, J. (2003). Singaporean students' mathematical thinking in problem solving and problem posing: An exploratory study. International Journal of Mathematical Education in Science and Technology, 34(5), 719-737. http://dx.doi.org/10.1080/00207390310001595401

Canakci, O., \& Ozdemir, A. S. (2011). The construction of mathematics problem solving attitude scale. Abant İzet Baysal Universitesi Egitim Fakultesi Dergisi, 11(1), 119-136.

De Corte, E. (2003). Intervention research: A tool bridging the theory-practice gap in mathematics education? In A. Rogerson (Ed.), The mathematics education into the $21^{\text {th }}$ century project proceedings of the international conference (pp. 45-55). Brno, Czech Republic: The Mathematics Education into the 21st Centrury Project.

Fitzpatrick, C. (1994). Adolescent mathematical problem solving: The role of metacognition, strategies and beliefs. Paper presented at the annual meeting of the AERA, April, New 
Orleans, LA. [SE 054 921]

Katwibun, D. (2004). Middle School Students' Mathematical Dispositions in a Problem-Based Classroom. (Doctoral dissertation). Oregon: Oregon State University.

Kupcu, A. R., \& Ozdemir, A.S. (2012). The middle school students' problem solving success of proportion related problems according to gender and proportional reasoning level. Kastamonu Education Journal, 20(2), 451-472.

Lampert, M. (1990). When the problem is not the question and the solution is not the answer: Mathematical knowing and teaching. American Educational Research Journal, 27, 29-63. http://dx.doi.org/10.3102/00028312027001029

McLeod, D. B. (1992). Research on affect in mathematics education: A reconceptualization. In DA Grouws (Ed.), Handbook of research on mathematics teaching and learning: A project of the National Council of Teachers of Mathematics (pp. 575-596). New York, NY: Macmillan.

Nancarrow, M. (2004). Exploration of Metacognition and Non-routine Problem based Mathematics Instruction on Undergraduate Student Problem Solving Success. (Doctoral dissertation). Florida, FL: Florida State University.

National Council of Teachers of Mathematics. (1989). Curriculum and evaluation standards. Reston, VA: Author.

NCTM (2000). Principles and standards for school mathematics. Reston, VA: Author.

Oladunni, M. O. (1998). An experimental study on the effectiveness of heuristic problem solving techniques on computational performance of students in math. Mathematics Educational Science Tech., 29(6), 867-874. http://dx.doi.org/10.1080/0020739980290608

Ozsoy, G. (2005). The relationship between problem solving skill and mathematics success. Gazi Egitim Fakultesi Dergisi (Gazi University Journal of Education Faculty), 25(3), 179-190.

Polya, G. (1990). How to solve it:A new aspect of mathematical method (2nd ed.). New Jersey, NY: Princeton.

Reusser, K., \& Stebler, R. (1997). Every word problem has a solution-the social rationality of mathematical modeling in schools. Learning and Instruction, 7(4), 309-327. http://dx.doi.org/10.1016/S0959-4752(97)00014-5

Reys, R. E., Suydam, M. N., Lindquist, M. M., \& Smith, N. L. (1998). Helping children learn mathematics. Boston, Massachusttes: Allyn \& Bacon.

Schoenfeld, A. H. (1992). Learning to think mathematically: Problem solving, metacognition and sense-making in mathematics. In D.A. Grouws (Ed.), Handbook of Research on Mathematics Teaching and Learning (pp. 334-370). New York, NY: Macmillan.

Soylu, Y., \& Soylu, C. (2006). The role of problem solving on the approach of achievement in mathematics courses. Inonu Universitesi Egitim Fakultesi Dergisi (Inonu University Journal of Faculty of Education), 7(11), 97-111. 


\section{Macrothink}

International Research in Education

ISSN 2327-5499

2015, Vol. 3, No. 2

Van de Walle, J. A. (1994). Elementary school mathematics teaching developmentally. New York, NY: Longman.

\section{Copyright Disclaimer}

Copyright reserved by the authors.

This article is an open-access article distributed under the terms and conditions of the Creative Commons Attribution license (http://creativecommons.org/licenses/by/3.0/). 